\title{
MODERN POLLEN RECORD ON BAT GUANO DEPOSIT FROM SIJU CAVE AND ITS IMPLICATION TO PALAEOECOLOGICAL STUDY IN SOUTH GARO HILLS OF MEGHALAYA, INDIA
}

\author{
Sadhan K. Basumatary* and SAmir K. Bera \\ Birbal Sahni Institute of Palaeobotany, Quaternary Palynology Division, 53, University Road, Lucknow-226007, Uttar Pradesh, India
}

\begin{abstract}
Meghalaya is well known for its rich tropical biodiversity and numerous natural caves. The Siju Cave of Meghalaya, also known as cave of the bat, is among the longest caves on the Indian subcontinent. The palynological study of fifty bat-guano samples from Siju Cave and of thirty surface soil and moss cushion from the area immediate surrounding the cave reflects the close similarity between the modern pollen and vegetation in the region in the two areas sampled. The resulting palynodata comprise mainly the native flora, dominated by riparian taxa like Duabanga, Syzygium, Careya, and Ficus, along with evergreen and deciduous elements in the region. The evergreen taxa Mesua, Elaeocarpus, and Garcinia, along with Impatiens, reflect the high precipitation in the region. The climate of the region and the vegetation are strongly influenced by the Simsang River, and the heavy rainfall results in the dominance of riparian taxa and other high-rainfall indicator taxa. The occurrence of pollen from Nepenthes khasiana, an endemic and endangered plant of Meghalaya, in bat guano is significant and may be due to its insectivorous and entomophilous nature. However, medicinal plants like Swertia chirata, Cinchona, and Rauvolfia are not encountered in the bat-guano sediments, despite their luxuriant growth around the cave, and these species could be avoided by the insects due to their alkaloid contain and bitter taste. The presence of highland taxa such as Pinus, Abies, Picea, and Larix in the bat guano deposit is significant and suggestive of high winds from higher altitudes, or the pollen may be introduced by the return of migratory Siberian birds during winter to the nearby Siju wildlife and bird sanctuary. The recovery of cerealia along with Areca catechu and Citrus pollen indicate the human activity in the region. The abundance of fungal remains, namely Meliola, Glomus, and Microthyriaceae along with degraded palynomorphs are suggestive of strong microbial activity under warm and humid conditions during sedimentation in the region. The main objective of this study is to identify the potential of bat guano for palaeoecological research and as supportive data for surface and sedimentary soil profiles in the South Garo Hills of Meghalaya. The palynodata from the bat guano of the Siju Cave provides a useful source for palaeoecological information for the South Garo Hills, where intensive natural and human-caused forest fires, heavy rainfall, and soil erosion occur every year and there is a relative scarcity of the lake, wetland, and swamp habitats that normally preserve pollen.
\end{abstract}

\section{INTRODUCTION}

The state of Meghalaya includes a significant portion of both Himalaya and Indo-Burma biodiversity hotspots (Mittermeier et al., 2005) and is globally known for Cherrapunjee, with the highest rainfall on earth and the endemic and endangered plant Nepenthes khasiana Hk. f., the symbolic plant of Meghalaya. The flora of Meghalaya is the richest in India and probably in the whole of Asia, with a close similarity to the flora of southeast Asia and southern China (Hooker, 1905). This region of the world is considered by botanists and geographers as one of the nuclear areas of early plant domestication (Vivilov, 1951; Sauer, 1952; Harris, 1972). The whole of the Garo Hills, especially the South Garo Hills, is also known as the ecological canvas of Meghalaya because of its unique biodiversity and numerous beautiful natural caves (Anonymous, 2006). The quantity and length of caves in Meghalaya far exceeds that of any other known karst region of India. Until recently only a few caves had been explored, but recent exploration has resulted in over 320 kilometers of cave passage mapped and over a thousand cave entrances documented in Meghalaya (Harries et al., 2008). As caves are natural open cavities in the earth, they function as natural sediment traps

*Corresponding author, sbasumatary2005@yahoo.co.in

Journal of Cave and Karst Studies, December 2014•173 
(White, 2007). In caves with large bat populations, guano (bat excreta) is present in sufficient quantities to be classified as a clastic sediment and serves as a source of useful climatic records (Leroy and Simms, 2006; White, 2007). In general, there are mainly three mechanisms for the incorporation of pollen into bat guano: bats can consume large numbers of flying insects, may consume pollen themselves, and may fly through a pollen-laden environment so that pollen and other dust particles often adheres to their body (Pendleton et al., 1996). Pollen in fragments of bat skin and hair may be lost during grooming, and dust containing pollen may be brought into the cave and deposited onto guano by air currents (Coles and Gilbertson, 1994). Where there are large colonies of bats their excrement accumulates on the cave floor below (Maher, 2006).

Many palaeoecological-research studies have been carried out on palynology of cave sediments, including bat guano and coprolites from other taxa and surface soil in different part of the globe, such as in Romania (Pop and Ciobanu, 1950; Boscaiu and Lupsa, 1967a,b; Feurdean et al., 2011; Geanta et al., 2012), the United States (Sears and Roosma, 1961; Davis, 1990; Nieves-Rivera 2003; Maher, 2006; Batina and Reese, 2011), Switzerland (Groner, 2004), Austria (Kral, 1968; Draxler, 1972), the UK (Coles et al., 1989; McGarry and Caseldine, 2004), Spain (Carrión, 1992; Carrión et al., 1999, 2006; Navarro Camacho et al., 2000, 2001), Belgium (Bastin, 1978; Bastin et al., 1986), Nepal (Denniston, et al., 2000), China (Qin et al., 1999; Zhang et al., 2004), and other parts of Asia (Hunt and Rushworth, 2005). In India, no previous studies have addressed the use of bat guano in cave sediments for palaeoecological study. We have discovered the Siju Cave to be one of the best sites to study bat guano for palynological research in the South Garo Hills of Meghalaya. In the Garo Hills, intensive natural and human-caused forest fires every year burn several centimeters of soil in the region (Fig. 2F). In addition, other factors like the high rainfall and tremendous soil erosion, along with the hilly terrain, make difficult the proper investigation and interpretation of modern pollen and vegetation relationships in the Garo Hills. The relatively scarcity of lake, wetland, and swamps has limited attempts to recover sediment cores from the Garo Hills for palaeoecological research. Although there are some scattered small lakes like Napak Lake in the South Garo Hills, these are not suitable for proper coring for palynological study. Previously, only a few preliminary palynological studies have been carried out in Meghalaya (Gupta and Sharma, 1985; Basumatary and Bera, 2007, 2010, 2012, Basumatary et al., 2013). Considering these previous limits to pollen studies in the region, we initiated the present palynological study on bat guano in Siju Cave in the South Garo Hills. The main objective of the study, as the first to be undertaken as a new innovation in pollen studies in India, was to identify the potential of bat guano as a reliable source to document modern pollen and vegetation in relation to climate in the South Garo hills.

\section{Physiography AND SoIL}

The South Garo Hills of Meghalaya are a unique feature of physiography where the Tura and Arabella Ranges run parallel in an east-west direction. The Tura Range runs from Siju to Tura, and the Arabella Range is to the north of the Tura range and gradually increases in height, eventually joining the Tura, which starts in the West Garo Hills to the south. The Garo Hills of Meghalaya are drained by many rivers and streamlets. The soil of the region is generally red-loamy, but sometimes varies from clay to sandy loam, and is rich in organic carbon with high nitrogen-supplying potential but is deficient in phosphorus and potassium. The soil $\mathrm{pH}$ ranges from acidic ( $\mathrm{pH} 5.0$ to 6.0 ) to strongly acidic ( $\mathrm{pH} 4.5$ to 5.0) (Directorate of Agriculture, Meghalaya, 2012).

\section{Climate}

The climate of the region is controlled by south-west and north-eastern monsoons. It is warm and humid in summer and cold and dry in winter. The maximum temperature during summer is $36^{\circ} \mathrm{C}$ and the minimum in winter is $4^{\circ} \mathrm{C}$. The relative humidity ranges from 70 to $98 \%$. Rainfall of the region ranges from 3900 to $6800 \mathrm{mmyr}^{-1}$ (Directorate of Agriculture, Meghalaya, 2012).

\section{Study Site and Vegetation}

The study site, Siju Cave in the South Garo Hills, is locally known as Dobakol, cave of the bat, as it is the home for thousands of bats. According to field observation and previous records (Sinha, 1994, 1999; Bates and Harrison, 1997) in Siju Cave, the dominant bat species are Rhinolophus subbadius, $R$. pusillus, $R$. pearsoni, and Miniopterus schreibersii; these are mainly insectivorous. The Siju Cave is situated at lat. $25^{\circ} 21^{\prime} 16.17^{\prime \prime} \mathrm{N}$ and long. $90^{\circ} 41^{\prime} 08.09^{\prime \prime} \mathrm{E}$ at $95 \mathrm{~m}$ asl (Fig. 1). It was first explored by the British Geologic Survey in 1920. This cave is one of the longest caves in the Indian subcontinent and contains some of the finest river passages to be found anywhere in the world. The cave has many unexplored chambers and labyrinths (Fig. 2A). The majestic formations inside the cave, especially in Princess Di's Chamber, are among the special attractions of the cave. In the northeast direction of Siju Cave, Simsang River (Fig. 2B), originates from the Tura peak area and supports luxuriant growth of marshy and aquatic plants. Naphak Lake and the Siju wildlife and bird sanctuary are located close to Siju Cave. During winter, Siberian ducks migrate to the bird sanctuary. Previous studies on the Siju Cave fauna are listed in Table 1, but this is the first attempt of a palynological study on bat guano in relation to modern pollen, 

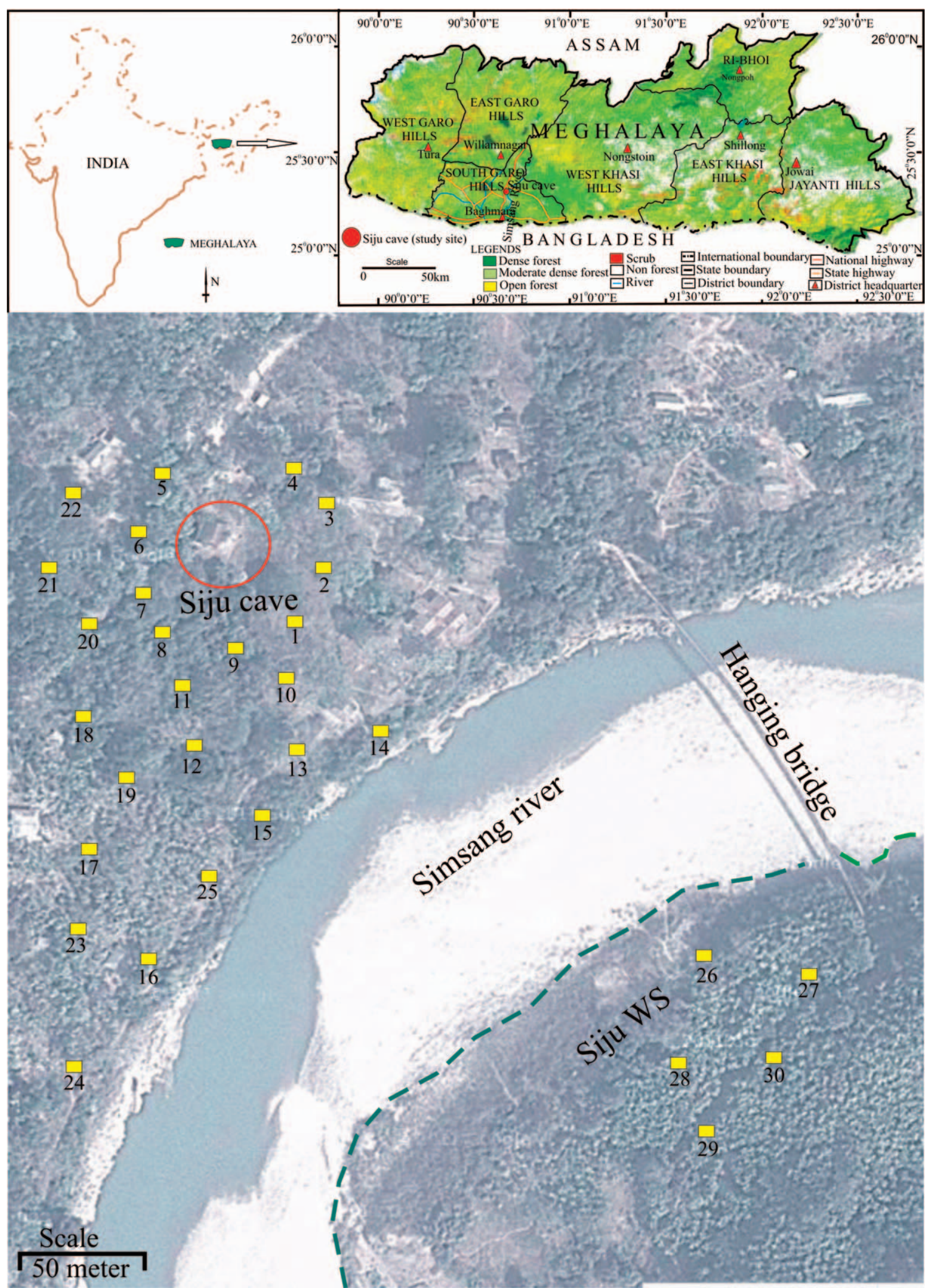

Figure 1. Map showing the location of Siju Cave in the South Garo Hills, Maghalaya. The numbers show the locations of the thirty surface samples. 

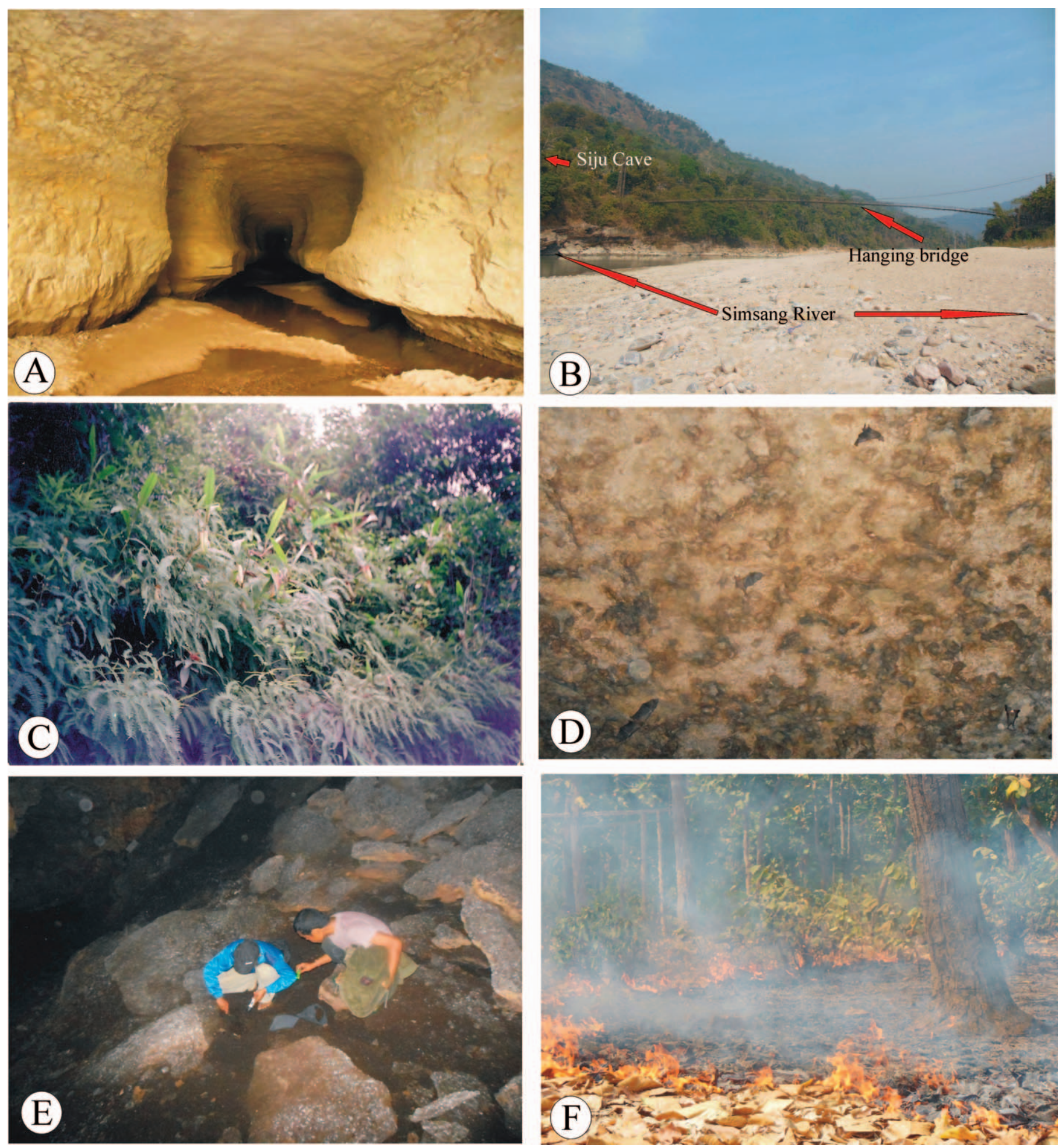

Figure 2. A. The entrance of Siju Cave, South Garo Hills, Meghalaya. B. The hanging bridge over the Simsang River connecting the Siju Cave area and the Siju wildlife and bird sanctuary, Meghalaya. C. A view of Nepenthes khasiana growing luxuriantly, intermixed with Gleichenia dichotoma, in the entrance of Siju Cave. D. A view of the bat colony in their resting chamber inside Siju Cave. E. Bat guano collection inside Siju Cave. F. A view of the forest floor burning during winter in South Garo Hills. 
Table 1. List of the recorded faunal taxa from Siju Cave, South Garo Hills, Meghalaya, with references.

\begin{tabular}{ll}
\hline Recorded Taxa & \multicolumn{1}{c}{ Reference } \\
\hline Coleoptera & Andrewes (1924) \\
Molluscas & Annandale and Chopra (1924) \\
Coleoptera & Blair (1924) \\
Diptera & Brunetti (1924) \\
Coleoptera & Cameron (1924) \\
Collembola & Carpenter (1924) \\
Diptera & Edwards (1924) \\
Araneids & Fage (1924) \\
Lepidoptera & Fletcher (1924) \\
Coleoptera & Fleutiaux (1924) \\
Tartarides & Gravely (1924) \\
Pisces & Hora (1924) \\
Rhynchota & Kemp and China (1924) \\
Diptera & Lamb (1924) \\
Lepidoptera & Meyrick (1924) \\
Gyrinidae & Ochs (1925) \\
Diptera & Patton (1924) \\
Hymenoptera & Rohwer (1924) \\
Myriapoda & Silvestri (1924) \\
Oligochaeta & Stephenson (1924) \\
Hymenoptera & Wheeler (1924) \\
Chiroptera & Bates and Harrison 1997 \\
Chiroptera & Sinha (1999) \\
Teleostei & Kottelat et al. (2007) \\
Arachnida, Brachyura, & \\
Palaemonidae, Isopoda, & \\
Diplopoda, Orthoptera, & \\
Dictyoptera, Coleopteran, & \\
Diptera and Pisces & Harries et al. (2008) \\
Diptera & Disney (2009) \\
\hline
\end{tabular}

vegetation, and climate, and it will be greatly helpful to further palaeoecological research in the South Garo Hills of Meghalaya and to place this region within a global context.

The vegetation of the region is dominated by riparian taxa, including Duabanga grandiflora, Syzygium polypetalum, Terminalia bellirica, Schima wallichii, Careya arborea, and Ficus pyriformis, intermixed with evergreen and deciduous elements such as Mesua ferrea, Elaeocarpus rugosus, Garcinia paniculata, Dillenia pentagyna, Emblica officinalis, Artocarpus chaplasha, and Adhatoda vasica. The endemic pitcher plant Nepenthes khasiana, locally known as memang-kokshi by the Garo people, grows intermixed with the pteridophytic flora (Fig. 2C). The pteridophytes are dominated by Lycopodium clavatum, Selaginella selaginoides, Dryopteris filixmas, Gleichenia dichotoma, Adiuntum caudatum, Cyathea gigantea, Angiopteris evecta, and Blechnum occidentale. The forest floor is formed by dense humus, is litter-laden, and is often covered by grasses such as Saccharum spontaneum, S. arundinaceum, Cynodon dactylon, and Neyraudia reynaudiana associated with sedges like Mariscus sumatrensis, Kyllinga monocephale, Fimbristylis dichotoma, Cyperus zollingeri, and Scleria terrestris. During the rainy season, Zingiberaceae like Curcuma aromatica and other dicotyledonous herbs such as Justicia simplex, Rungia pectinata, Amaranthus aspera, Evolvulus nummularius, and Polygonum orientale are present in large numbers.

\section{Materials And Methods}

The location of Siju Cave was recorded by GPS with coordinates based on WGS1984. The cave was surveyed in detail, and fifty samples of approximately $50 \mathrm{~g}$ of bat guano were collected randomly from the floor of the bats' resting chamber inside the cave (Figs. 2D, E). A total of thirty surface samples of both soil and moss cushion were collected randomly from the area immediately outside Siju Cave. We also collected polliniferous plant materials for proper identification of taxa in the region by their pollen morphology. The specimens were placed in the Birbal Sahni Institute of Palaeobotany (BSIP) Herbarium.

The bat guano and surface samples were processed employing the standard acetolysis method (Erdtman, 1953). The samples were treated with $10 \%$ aqueous $\mathrm{KOH}$ solution to deflocculate the pollen and spores from the sediments followed by $40 \% \mathrm{HF}$ treatment to dissolve silica content. Then the conventional procedure of acetolysis was followed using the acetolysis mixture 9:1 anhydrous acetic acid and concentrated $\mathrm{H}_{2} \mathrm{SO}_{4}$. Finally the material was kept in a $50 \%$ glycerin solution with a drop of phenol. Between 450 and 600 pollen and spores per sample were counted to produce the pollen spectra. Plant elements in the study were categorized into arboreals (trees, shrubs, and epiphytes), nonarboreals (terrestrial herbs and marshy taxa), highland taxa, ferns, and fungal remains with degraded palynomorphs. For the precise identification of fossil palynomorphs in the sediments, we consulted the reference pollen slides available at Birbal Sahni Institute of Palaeobotany (BSIP) herbarium of India, as well as the pollen photographs in the published literature (Chauhan and Bera, 1990; Nayar, 1990; Bera et al., 2009). Photodocumentation of the palynomorphs was made using an Olympus BX-61 microscope with DP25 digital camera under $40 \times$ magnification (Fig. 3). The pollen spectra were made using Microsoft Excel program and modified in Corel Draw-12 software. The frequency percentage of the recovered palynomorphs has been calculated in terms of the total palynomorphs.

\section{RESUlts}

The modern pollen spectra of bat guano from Siju Cave and from the surface soil and moss cushion from its immediate surroundings are discussed below and provide an overview of modern pollen in relation to vegetation and climate in the region. The total of fifty modern bat 

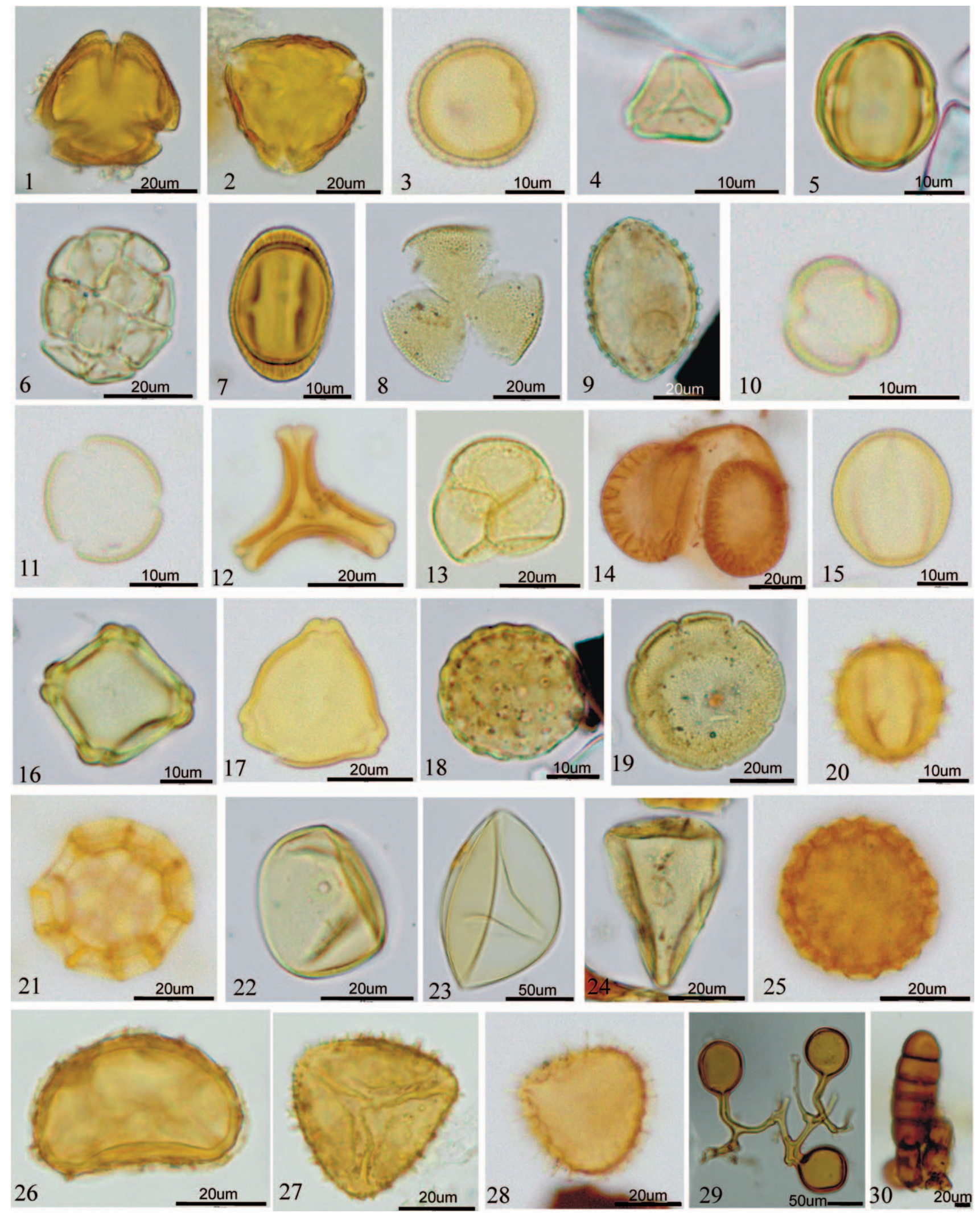

Figure 3. Palynoassemblage recovered from the bat guano and surface sample from South Garo Hills, Meghalaya. 1. Mesua, 2. Schima, 3. Emblica, 4. Syzygium, 5. Terminalia, 6. Albizia, 7. Duabanga, 8. Dipterocarpaceae, 9. Areca, 10. Elaeocarpus, 11. Dillenia, 12. Dendropthoe, 13. Nepenthes, 14. Pinus, 15. Quercus, 16. Alnus, 17. Betula, 


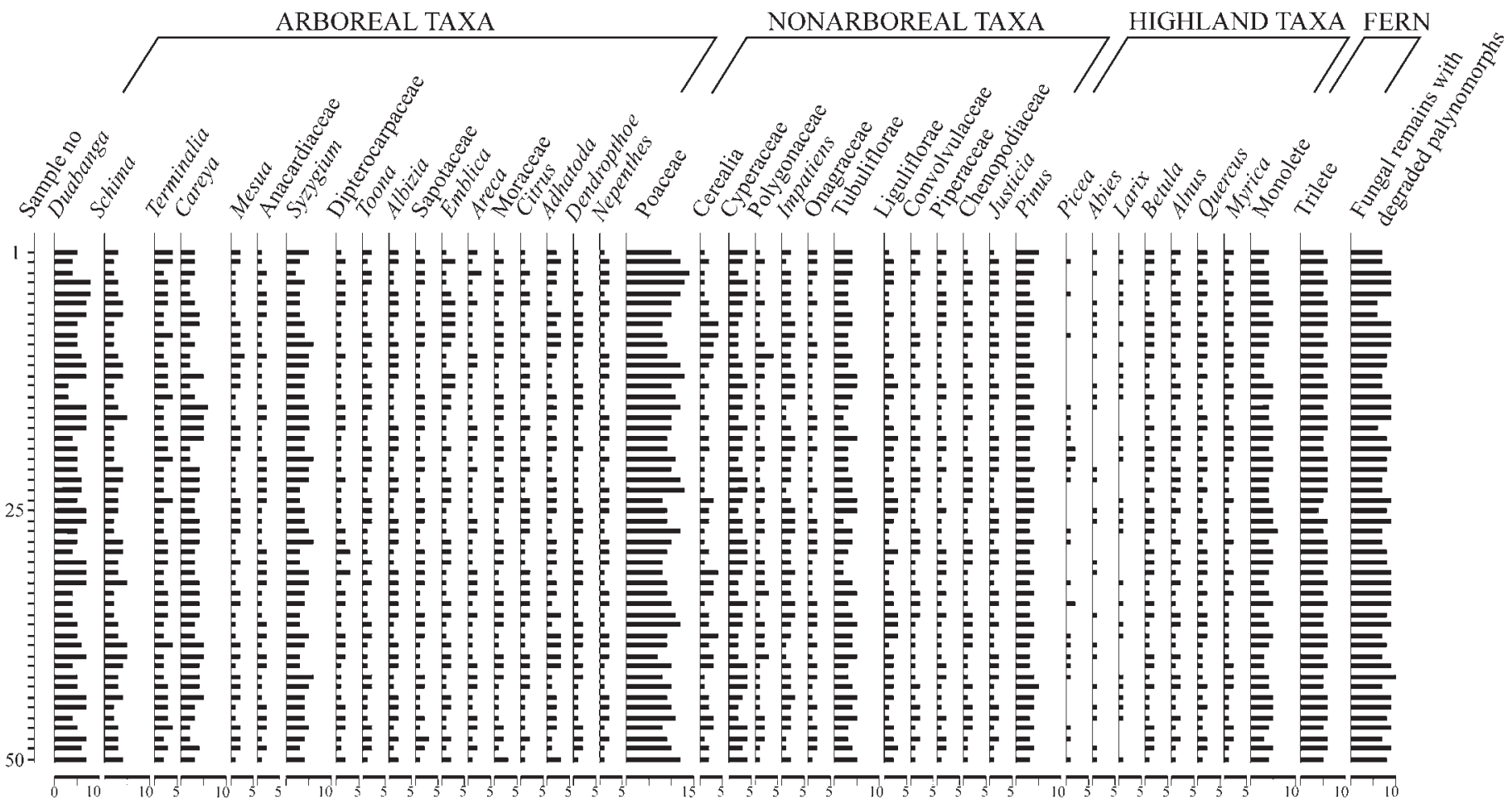

Figure 4. Pollen spectra of bat guano samples from Siju Cave, South Garo Hills, Meghalaya.

guano samples collected randomly from inside the cave are dominated by arboreals $(42 \%)$, followed by nonarboreals $(35 \%)$, fungal remains with degraded palynomorphs $(10 \%)$, ferns $(6 \%)$, and highland taxa $(5 \%)$ (Fig. 4). The major arboreals include Duabanga, Schima, Syzygium, and Careya and are represented by maximum values up to $10 \%$. Other associated taxa, such as Schima, Semecarpus, Albizia, Adhatoda, and Nepenthes have values of 1 to $6 \%$. Nonarboreals like Poaceae, Cyperaceae, and Tubuliflorae have values of 1 to $15 \%$. Ferns, both monolete and trilete, exhibit an average value of $4 \%$ and $5 \%$ respectively. Fungal remains like Microthyriaceae, Glomus, Diplodia, and Meliola are represented by maximum values up to $6 \%$. Among the highland taxa, Pinus is recorded at values of 2\%, whereas its associated taxa like Abies and Picea are only encountered in trace amounts (Fig. 4).

The thirty surface soil and moss cushions samples collected randomly from the immediate vicinity of the cave are dominated by arboreals $(40 \%)$, followed by nonarboreals $(37 \%)$, ferns $(12 \%)$, fungal remains with degraded palynomorphs (7\%), and highland taxa (4\%) (Fig. 5). The major arboreals include Duabanga, Syzygium, Anacardiaceae, Moraceae, and Careya and are represented by maximum values up to $8 \%$. The other associated taxa such as Mesua, Elaeocarpus, Schima, Dillenia, Terminalia, Adhatoda, and Nepenthes have values of 1 to $5 \%$. Among nonarboreals like Poaceae, Tubuliflorae, Onagraceae and Impatiens the values range between 1 to $18 \%$. Ferns, both monolete and trilete, have an average value of $5 \%$ and $6 \%$ respectively. Fungal remains like Microthyriaceae, Cookeina, Tetraploa, and Glomus are represented by a maximum value of $5 \%$. The highland taxa Pinus is recorded at the value of $3 \%$, whereas associated taxa Abies and Picea are represented by variable values.

\section{DisCUSSION}

There are some difference between pollen percentages preserved in the bat guano and the surface samples from the vicinity of Siju Cave, although, in general, the palynodata reflect a close similarity between the bat guano and surface samples: (i) the pollen diversity from bat guano is higher than the surface samples, (ii) the number of arboreal taxa is higher in the bat guano samples, (iii) the Dipterocarpaceae pollen is markedly present in the bat guano, but is not found in the samples collected from the immediate vicinity of the cave, (iv) the fern spores are

18. Chenopodiaceae, 19. Convolvulaceae, 20. Tubuliflorae, 21. Liguliflorae, 22. Poaceae, 23. Cerealia, 24. Cyperaceae, 25. Polygonaceae, 26. Monolete, 27. Trilete, 28. Lycopodium, 29. Glomus, 30. Meliola. 


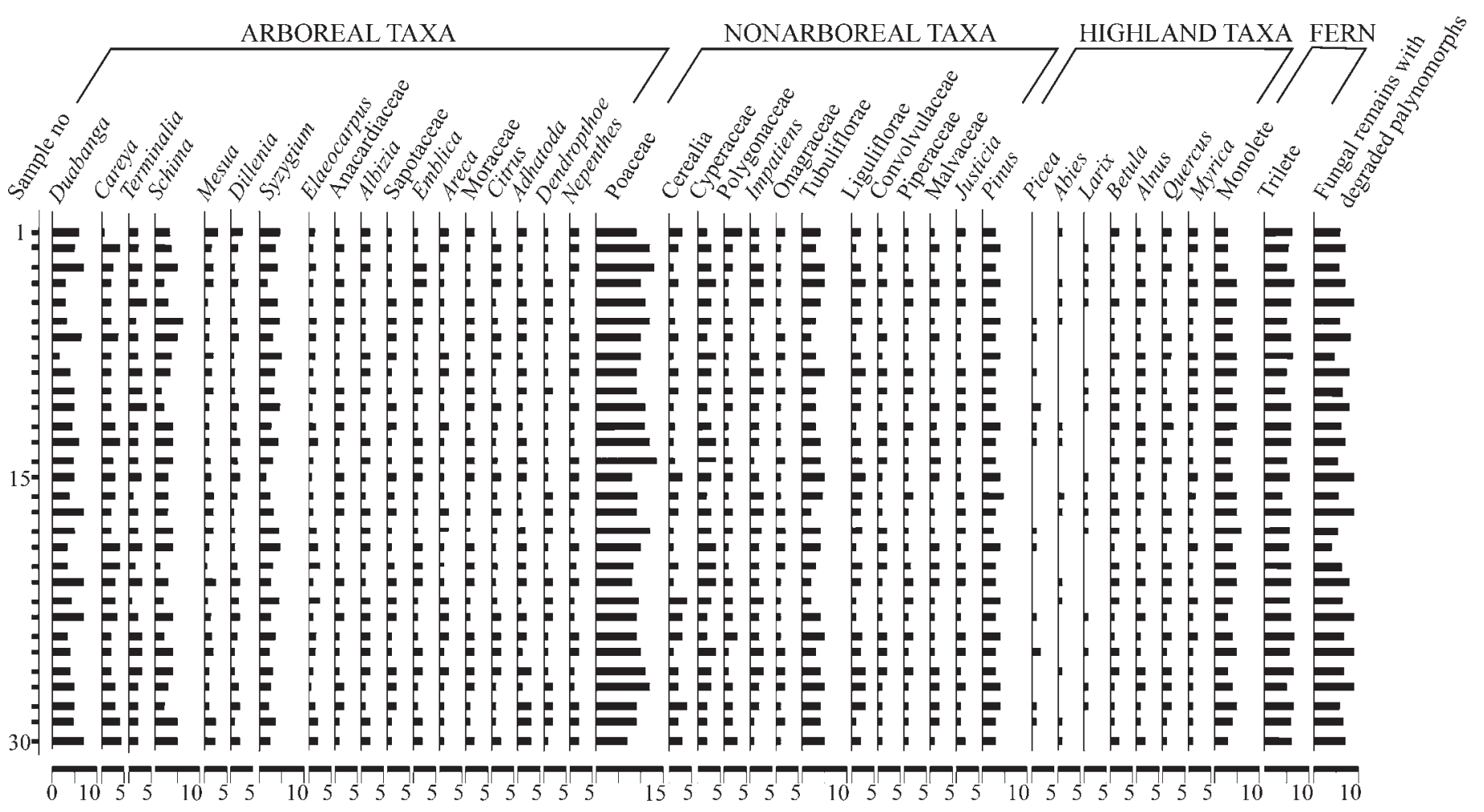

Figure 5. Pollen spectra of surface samples from the immediate vicinity of Siju Cave, South Garo Hills, Meghalaya.

comparatively few in the bat guano samples, and (v) the fungal remains, along with degraded palynomorphs, are comparatively higher in the bat guano samples.

\section{Relationship of Palynoassemblage, Vegetation, and Climate}

The bat guano from Siju Cave and the forest surface samples of moss cushion and soil collected from the immediate vicinity both contain pollen indicative of the tropical riparian forest intermixed with evergreen and deciduous elements under warm and humid climatic condition. Among the arboreals, the samples principally reflect the proximity of riparian taxa like Duabanga, Syzygium, Careya, and Ficus in the palynoassemblage that grows along the edge of the river Simsang. The associated evergreen and deciduous elements like Mesua, Elaeocarpus, Garcinia, Schima, Dillenia, Albizia, and Sapotaceae also exhibit 30 to $42 \%$ totals indicative of the heavy rainfall in the region. The presence of evergreen taxa, along with Piperaceae and Euphorbiaceae, suggests heavy rainfall in the region (Nair et al., 2010), which is reflected by the observed palynoassemblage in the sediments from both inside and outside of the cave. The occurrence of Dendrophthoe (epiphytic plants) pollen in the palynoassemblage is significant and reflects the existence of a primary forest that receives heavy rainfall in the region. The presence of Areca (betel nut) pollen along with cerealia and Citrus (orange) are strongly indicative of the human activity in the area. The presence of the highland taxa
Pinus, Betula, Abies, Picea, and Larix in the bat guano deposit is significant and suggestive of strong winds from higher altitudes, or they may have been introduced by the migration of Siberian birds to the nearby Siju wildlife and bird sanctuary during winter. The palynodata of the surface samples from the immediate vicinity of the cave also reflect the riparian forest and are an exact match with the cave sample of bat guano. That both the vegetation and climate of the region are strongly governed by the Simsang River, along with the heavy rainfall, is indicated by the dominance of the riparian taxa Duabanga, Ficus, and Careya and other heavy-rainfall indicator taxa like Mesua, Syzygium, and Elaeocarpus. The samples from inside the cave also reflect local and regional floras quite well (Burney and Burney, 1993; Carrión et al., 2006), and the pollen contained in the bat guano matches well that in the surface sediments of lake and peat (Maher, 2006) that supports our palynodata. The abundance of Nepenthes khasiana in bat guano is significant and suggests the presence of insectivorous and riparian habitat growing in very limited pockets in and around the area. The presence of Nepenthes pollen is strongly suggestive of heavy rainfall and a perennial water system in the region, because Nepenthes khasiana generally grows in the shade along rivers and streamlets in Meghalaya (Haridasan and Rao, 1985). The preservation of Dipterocarpaceae pollen in the bat guano is informative with regard to the size of the areas sampled by the bats, as it does not grow near the Siju Cave and the closest plants are several kilometers distance from the study area. Leroy 
and Simms (2006) noted that bats can migrate hundreds of kilometers from their shelter and is supported by our pollen data, which strongly suggest that the bats fly several kilometers for their food. The fern spores, especially Cyathea, Dryopteris, and Pteris, in the bat guano are local in origin and grew in the immediate vicinity of the cave. Their presence may also be due to the influence of wind activity. Caves with a large entrance and strong air circulation are likely to have higher pollen presence resulting from wind than caves with smaller entrances and minimal air circulation (Burney and Burney, 1993). However, the occurrence of terrestrial ferns, especially Gleichenia, Dryopteris, and Lycopodium, signifies high rainfall and humid climatic conditions in the area (Basumatary et al., 2013), which is exactly reflected in the palynoassemblage of the studied samples. The abundance of fungal remains such as Meliola, Cookeina, Microthyriaceae, and Diplodia, along with degraded palynomorphs, is strongly indicative of warm and humid climatic condition during sedimentation in the region. The presence of Glomus with hyphae in surface-soil and moss-cushion samples is strongly indicative of high soil erosion in the region. Medicinal plants like Swertia chirata and Rauvolfia serpentina are not encountered in the bat guano, although they are present in the luxuriant growth in the vicinity of the cave. Their absence may be due to their bitter in taste and avoidance by insects that might in turn be eaten by the bats.

\section{Conclusions}

The palynological study on bat guano from Siju Cave is the first to be conducted in India. The palynodata from both the modern bat guano and surface samples from the immediate vicinity of the cave are very similar and indicate the existence of mainly riparian forest intermixed with both evergreen and deciduous taxa that exactly coincides with the extant vegetation. The bat guano deposit in Siju Cave can be considered as a reliable source of palaeoecological data that can be used to support data from surface and sedimentary soil profiles and to substitute for the scarcity of lakes, swamps, and wetlands in Meghalaya, with the caveat that bats can forage long distances from their roost site in the cave and may accumulate pollen from plants not found in the immediate vicinity of the cave. Lastly, multidisciplinary studies that integrate pollen data from caves with paleontological, archaeological, zoological, and geological data could play an important role in any palaeoecological study of the South Garo Hills of Meghalaya and at the global level.

\section{ACKNOWLEDGEMENTS}

Authors thank to the Director, Birbal Sahni Institute of Palaeobotany (BSIP), Lucknow, India, for infrastructure facility and permission to publish the paper. We also thank a number of forest officials for their help during field work.

\section{REFERENCES}

Andrewes, H.E., 1924, Coleoptera of the Siju cave, Garo Hills, Assam: I Carabidae: Records of the Indian Museum, v. 26, p. 115-117.

Annandale, N., and Chopra, B., 1924, Molluscas of the Siju cave, Garo Hills, Assam: Records of the Indian Museum, v. 26, p. 33-40.

Anonymous, 2006, Meghalaya resource FlBIOSPHERE_RESERVES. http://meghalaya.nic.in/tourism/cave.htm [accessed 20 November 2006].

Bastin, B., 1978, L'analyse pollinique des stalagmites: une nouvelle possibilité d'approach des fluctuations climatiques du Quaternaire: Annales de la Société Géologique de Belgique, v. 101, p. 13-19.

Bastin, B., Cordy, J.-M., Gewelt, M., and Otte, M., 1986, Fluctuations climatique enregistrées depuis 125000 ans dans les couches de remplissage de la GrotteScladina (Provence de Namur, Belgique): Bulletin de l'Association Française pour l'étude du Quaternaire, v. 23, no. 2-3, p. 168-177. doi:10.3406/quate.1986.1808.

Basumatary, S.K., and Bera, S.K., 2007, Modern pollen-spore assemblage from sediment of tropical moist deciduous forest, East Garo Hills, Meghalaya: Journal of Palynology, v. 43, p. 111-118.

Basumatary, S.K., and Bera, S.K., 2010, Development of vegetation and climate change in West Garo Hills since late Holocene: pollen sequence and anthropogenic impact: Journal of the Indian Botanical Society, v. 89, p. 143-148.

Basumatary, S.K., and Bera, S.K., 2012, Vegetation succession and climate change in western Garo Hills, Meghalaya, India since 11,643 years BP: a palynological record: International Journal of Earth Science and Engineering, v. 5, no. 4, p. 749-758.

Basumatary, S.K., Dixit, S., Bera, S.K., and Mehrotra, R.C., 2013, Modern pollen assemblages of surface samples from Cherrapunjee and its adjoining areas, Meghalaya, northeast India: Quaternary International, v. 298, p. 68-79.

Bera, S.K., Basumatary, S.K., and Dixit, S., 2009, Studies on pollen morphology and phenological characteristics of some economically important arborescent taxa of tropical forest lower Brahmaputra Valley, Assam, North East India: Journal of Palynology, v. 43, p. 1-9.

Blair, K.G., 1924, Coleoptera of the Siju Cave, Garo Hills, Assam: IV Histeridae, Hydrophilidae, Erotylidae, Lathridiidae, Tenebrionidae and Hylophilidae: Records of the Indian Museum, v. 26, p. 120-122.

Brunetti, E., 1924, Diptera of the Siju Cave, Garo Hills, Assam: I. Tipulidae, Tabanidae, Anthomyidae, Acalyptrate Muscidae and Phoridae: Records of the Indian Museum, v. 26, p. 99-106.

Bates, P.J.J., and Harrison, D.L., 1997, Bats of the Indian Subcontinent, Kent, Harrison Zoological Museum, 268 p.

Batina, M.C., and Reese, C.A., 2011, A Holocene pollen record recovered from a guano deposit: Round Spring Cavern, Missouri, USA: Boreas, v. 40, no. 2, p. 332-341. doi:10.1111/j.1502-3885.2010.00186.x.

Boscaiu, N., and Lupsa, V., 1967a, Palynological research in the "Grota Haiducilor" Cave near the Herculaneumspa (Romania): Revue Roumaine de Biologie, Série de Botanique, v. 12, p. 137-140.

Boscaiu, N., and Lupsa, V., 1967b, Cercetări palinologice în PesteraVeterani din Defileul Dunării, Contributii Botanice, p. 39-46.

Burney, D.A., and Burney, L.P., 1993, Modern pollen deposition in cave sites: experimental results from New York State: New Phytologist, v. 124, p. 523-535. doi:10.1111/j.1469-8137.1993.tb03844.x.

Cameron, M., 1924, Coleoptera of the Siju Cave, Garo Hills, Assam: II. New species of Staphylinidae: Records of the Indian Museum, v. 26, p. $118-119$.

Carpenter, G.H., 1924, Collembola of the Siju Cave, Garo Hills, Assam: Records of the Indian Museum, v. 26, p. 285-289.

Carrión, J.S., 1992, Late Quaternary pollen sequence from Carihuela Cave, southeastern Spain: Review of Palaeobotany and Palynology, v. 71, p. 37-77. doi:10.1016/0034-6667(92)90157-C.

Carrión, J.S., Munuera, M., Navarro, C., Burjachs, F., Dupré, M., and Walker, M.J., 1999, The palaeoecological potential of pollen records in caves: the case of Mediterranean Spain: Quaternary Science Reviews, v. 18, p. 1061-1073. doi:10.1016/S0277-3791(98)00002-X.

Carrión, J.S., Scott, L., and Marais, E., 2006, Environmental implications of pollen spectra in bat droppings from southeastern Spain and potential for palaeoenvironmental reconstructions: Review of Palaeo- 
botany and Palynology, v. 140, p. 175-186. doi:10.1016/j.revpalbo. 2006.03.007.

Chauhan, M.S., and Bera, S.K., 1990, Pollen morphology of some important plants of tropical deciduous sal (Shorearobusta) forests, district Sidhi, Madhya Pradesh: Geophytology, v. 20, no. 1, p. 30-36.

Coles, G.M., and Gilbertson, D.D., 1994, The airfall-pollen budget of archaeologically important caves: Creswell Crags, England: Journal of Archaeological Science, v. 21, p. 735-755. doi:10.1006/jasc.1994.1073.

Coles, G.G., Gilberton, D.D., Hunt, C.O., and Jenkinson, R.D.S., 1989, Taphonomy and the palynology of cave deposits: Cave Science, v. 16, p. 83-89.

Denniston, R.F., Gonza'lez, L.A., Asmerom, Y., Sharma, R.H., and Reagan, M.K., 2000, Speleothem Evidence for Changes in Indian Summer Monsoon Precipitation over the Last; 2300 Years. Quaternary Research, v. 53, p. 196-202.

Davis, O.K., 1990, Caves as sources of biotic remains in arid western North America: Palaeogeography, Palaeoclimatology, Palaeoecology, v. 76, p. 331-348. doi:10.1016/0031-0182(90)90119-R.

Disney, R.H.L., 2009, Scuttle flies (Diptera: Phoridae) from caves in Meghalaya, India: Journal of Cave and Karst Studies, v. 71, no. 1, p. 81-85.

Draxler, I., 1972, Palynologische Untersuchungen an Sedimenten aus der Salzofen-höhleim Toten Gebirge: Annalen des Naturhistorischen Museums in Wien, v. 76, p. 161-186.

Edwards, F.W., 1924, Diptera of the Siju cave, Garo Hills, Assam: II. Chironomidae: Records of the Indian Museum, v. 26, p. 107-108.

Erdtman, G., 1953, An Introduction to Pollen Analysis, New York, Ronald Press, 239 p.

Fage, L., 1924, Araneids from the Siju Cave, Garo Hills, Assam: Records of the Indian Museum, v. 26, p. 63-67.

Feurdean, A., Persoiu, A., Pazdur, A., and Onac, B.P., 2011, Evaluating the palaeoecological potential of pollen recovered from ice in caves: A case study from Scărisoara Ice Cave, Romania: Review of Palaeobotany and Palynology, v. 165, p. 1-10. doi:10.1016/j.revpalbo.2011. 01.007 .

Fletcher, T.B., 1924, Lepidoptera of the Siju cave, Garo Hills, Assam I Pyralidae: Records of the Indian Museum, v. 26, 113 p.

Fleutiaux, E., 1924, Coleoptera of the Siju cave, Garo Hills, Assam III Elateridae: Records of the Indian Museum, v. 26, 119 p.

Geantă, A., Tantău, I., Tămas, T., and Johnston, V.E., 2012, Palaeoenvironmental information from the palynology of an 800 year old bat guano deposit from Măgurici Cave, NW Transylvania (Romania) Review of Palaeobotany and Palynology, v. 174, p. 57-66. doi:10.1016/j.revpalbo.2011.12.009.

Gravely, F.H., 1924, Tartarides from the Siju cave, Garo Hills, Assam: Records of the Indian Museum, v. 26, p. 61-62.

Groner, U., 2004, Palynology and sediment data from the high alpine karst cave on Jungfraujoch, Switzerland: Eclogae Geologicae Helveticae, v. 97, p. 237-243. doi:10.1007/s00015-004-1122-9.

Gupta, H.P., and Sharma, C., 1985, Pollen analysis of modern sediments from Khasi and Jaintia hills, Meghalaya, India: Journal of Palynology, v. 21, p. 167-173.

Haridasan, K., and Rao, R.R., 1985, Forest Flora of Meghalaya, vol I, Dehradun, India, Bishen Singh Mahendra Pal Singh, p. 1-451.

Harris, D.R., 1972, The origin of agriculture in the tropics: American Scientist, v. 60, p. 180-193.

Harries, D.B., Ware, F.J., Fischer, C.W., Biswas, J., and Kharpran-Daly, B.D., 2008, A review of the biospeleology of Meghalaya, India: Journal of Cave and Karst Studies, v. 70, no. 3, p. 163-176.

Hooker, J.D., 1905, Himalayan Journals: Notes of a Naturalist in Bengal, the Sikkim and Nepal Himalayas, the Khasia Mountains \&c, London, Ward, Lock, Bowden and Co., $639 \mathrm{p}$.

Hora, S.L., 1924, Fish of the Siju cave, Garo Hills, Assam: Records of the Indian Museum, v. 26, p. 27-31.

Hunt, C.O., and Rushworth, G., 2005, Pollen taphonomy and airfall sedimentation in a tropical cave: the West Mouth of The Great Cave of Niah in Sarawak, Malaysian Borneo: Journal of Archaeological Science, v. 32, p. 465-473. doi:10.1016/j.jas.2004.11.005.

Kemp, S., and China, W.E., 1924, Rhynchota of the Siju cave, Garo Hills, Assam: Records of the Indian Museum, v. 26, p. 93-97.

Kottelat, M., Harries, D.R., and Proudlove, G.S., 2007, Schistura papalifera, a new species of cave loach from Meghalaya, India (Teleostei: Balitoridae): Zootaxa, no. 1393, p. 35-44.
Kral, F., 1968, Pollenanlytische Untersuchungen zur Frage des Alters der Eisbildungen in der Dachstein-Rieseneishohle: Die Höhle, v. 19, p. $41-51$.

Lamb, C.G., 1924, Diptera of the Siju cave, Garo Hills, Assam III Dolichopodidae: Records of the Indian Museum, v. 26, p. 108-112.

Leroy, S.A.G., and Simms, M.J., 2006, Iron age to medieval entomogamous vegetation and Rhinolophus hipposideros roost in South-Eastern Wales (UK). Palaeogeography, Palaeoclimatology, Palaeoecology, v. 237, p. 4-18. doi:10.1016/j.palaeo.2005.11.025.

Maher, L.J., Jr., 2006, Environmental information from guano palynology of insectivorous bats of the central part of the United States of America: Palaeogeography, Palaeoclimatology, Palaeoecology, v. 237, p. 19-31. doi:10.1016/j.palaeo.2005.11.026.

McGarry, S.F., and Caseldine, C., 2004, Speleothem Palynology: an undervalued tool in Quaternary studies: Quaternary Science Review, v. 23, p. 2389-2404. doi:10.1016/j.quascirev.2004.06.007.

Meyrick, E., 1924, Lepidoptera of the Siju cave, Garo Hills, Assam II Tineidae: Records of the Indian Museum, v. 26, 114 p.

Mittermeier, R.A., Gil, P.R., Hoffmann, M., Pilgrim, J., Brooks, T., Mittermeier, C.G., Lamoreux, J., and da Fonseca, G.A.B., 2005, Hotspots revisited: Earth's Biologically Richest and Most Endangered Terrestial Ecosystems, Arlington, Virginia, Conservation International, $392 \mathrm{p}$.

Nair, K.M., Padmalal, D., Kumaran, K.P.N., Sreeja, R., Limaye, R.B., and Srinivas, R., 2010, Late Quaternary evolution of Ashtamudie-Sasthamkotta lake systems of Kerala, south west India: Journal of Asian Earth Science, v. 37, p. 361-372. doi:10.1016/j.jseaes.2009.09.004.

Navarro Camacho, C., Carrión, J.S., Navaro, J., Munuera, M., and Prieto, A.R., 2000, An experimental approach to the palynology of cave deposits: Journal of Quaternary Science, v. 15, p. 603-619. doi:10.1002/1099-1417(200009)15:6<587::AID-JQS533>3.0.CO;2-2.

Navarro, C., Carrión, J.S., Munuera, M., and Prieto, A.R., 2001, Cave surface pollen and the palynological potential of karstic cave sediments in palaeoecology: Review of Paleobotany and Palynology, v. 117 , p. $245-265$. doi:10.1016/S0034-6667(01)00095-1.

Nayar, T.S., 1990, Pollen Flora of Maharashtra State, India, New Delhi, Today and Tomorrow's Printers \& Publishers, $157 \mathrm{p}$.

Nieves-Rivera, Á.M., 2003, Mycological Survey of Río Camuy Caves Park, Puerto Rico: Journal of Cave and Karst Studies, v. 65, no. 1, p. $23-28$.

Ochs, G., 1925, Descriptions of new Asiatic Gyrinidae: Records of the Indian Museum, v. 27, p. 193-204.

Patton, W.S., 1924, Diptera of the Siju cave, Garo Hills, Assam IV Nycteribiidae: Records of the Indian Museum, v. 26, 112 p.

Pendleton, M., Bryant, V.M., and Pendleton, B.B., 1996, Entomopalynology, in Jansonius, J., and McGregor, D.C., eds., Palynology: Principles and Applications, Dallas, American Association of Stratigraphic Palynologists Foundation, Contributions Series, v. 3, p. 939-943.

Pop, E., and Ciobanu, I., 1950, Analize de polen în ghiata dela Scarisoara, Analele Academiei Republicii Populare Romane, seria Geologie, Geografie, Biologie, Stiin Tehnice si Agricole, III, p. 23-50.

Qin, Xiaoguang, Tan, Ming, Liu, Tungsheng, Wang, Xianfeng, Li, Tieying, and Lu, Jinpo, 1999, Spectral analysis of a 1000-year stalagmite lamina-thickness record from Shihua Cavern, Beijing, China, and its climatic significance: The Holocene, v. 9, p. 689-694. doi:10.1191/095968399671019413.

Rohwer, S.A., 1924, Hymenoptera of the Siju cave, Garo Hills, Assam II Description of a new Braconid: Records of the Indian Museum, v. 26, p. $124-125$.

Sauer Carl, O., 1952, Agricultural Origin and Dispersals, New York, American Geographical Society, Bowman Memorial Lectures series 2, $131 \mathrm{p}$.

Sears, P.B., and Roosma, A., 1961, A climatic sequence from two Neveda caves: American Journal of Science, v. 259, p. 669-678. doi:10.2475/ ajs.259.9.669.

Silvestri, F., 1924, Myriapoda from the Siju cave, Garo Hills, Assam: Records of the Indian Museum, v. 26, p. 71-79.

Sinha, Y.P., 1994, Occurrence of Kashmir Cave Bat Myotis longipes (Dobson, 1873) in Meghalaya, India. Geobios New Reports, v. 13, p. 72-73. Sinha, Y.P., 1999, Bats of the Siju Cave, South Garo Hills District, Meghalaya, India: taxonomy and bionomics: Records of the Zoological Survey of India, v. 97, p. 101-122.

Stephenson, J., 1924, Oligochaeta of the Siju cave, Garo Hills, Assam: Records of the Indian Museum, v. 26, p. 127-135. 
Vivilov, N.I., 1951, The Origin, Variation, Immunity and Breeding of Cultivated Plants, Waltham, Massachusetts, Chronica Botanica, $364 \mathrm{p}$.

Wheeler, W.M., 1924, Hymenoptera of the Siju cave, Garo Hills, Assam I Triglyphothrix striatidens Emery as a cave ant: Records of the Indian Museum, v. 26, p. 123-124.
White, W.B., 2007, Cave sediments and paleoclimate. Journal of Cave and Karst Studies, v. 69, p. 76-93. Zhang, Meiliang, Yuan, DaoXian, Lin, Yushi, Qin, Jiaming, Bin, Li, Cheng, Hai, and Edwards, R.L., 2004, A 6000-year high-resolution climatic record from a stalagmite in Xiangshui Cave, Guilin, China: The Holocene, v. 14, p. 697-702. doi:10.1191/0959683604hl748rp. 